\title{
A Multimodal Discourse Analysis of the Most Viewed Reggaeton Video on YouTube by the LIV Super Bowl Halftime Show
}

\author{
Gustavo Moreno López \\ University of Guanajuato, MEXICO \\ Division of Social Sciences and Humanities
}

Received: 1 June 2020 - Accepted: 26 October 2020 • Published Online: 21 November 2020

\begin{abstract}
We are what they eat and what we listen as well. Concerning this idea, it is essential to mention that reggaeton is one of the most consumed genres in many countries. Furthermore, to the extent that people regularly listen to music on platforms and express to like reggaeton in recent years, they may want to know more about what they are consuming. However, in the related literature, there is evidence of a negative impact on the women's image and heavy load of sexual content (Gallucci, 2008; Noriega, 2014; Ramírez, 2012). Therefore, the present article analyses the discourse of "no me conoce" by J. Balvin, Bad Bunny, and Jhay Cortez. The lyrics and images were analyzed using systemic functional linguistics (Halliday \& Matthiessen, 2003) and visual semiotics (Machin, 2010). The findings suggest that this genre contributes negatively to educational stances, such as writing proficiency, vocabulary range, and reading comprehension.
\end{abstract}

Keywords: metafunctions, multimodal discourse analysis, visual semiotic analysis.

\section{Introduction}

The definition of discourse has been constructed since the early 8os. For instance, Brown and Yule (1983) define it as any form of language use. It means that any spoken or written speech can be treated as a discourse. Furthermore, Carter (1993) refers to discourse in three denotations: topics used in specific contexts, discourse and text as spoken and written, respectively, and used to establish significance to the sentences (as cited in Drid, 2010). In addition, discourse analysis "attempts to study the organization of language above the sentence or above the clause; and therefore to study large linguistic units such as conversational exchanges or written texts" (Stubbs, 1983: 32). Morover, Van Els (1984), states that discourse analysis is "the study of language in context will offer a deeper insight into how meaning is attached to utterances than the study of language in isolated sentences" (p. 94). Concerning these previous definitions, I will present the study of the song "No me conoces" through a multimodal analysis of its lyrics and images. First, in the following two sections, I provide the background on the social phenomenon and an introduction to this music genre and singers.

(C) Authors. Terms and conditions of Creative Commons Attribution 4.0 International (CC BY 4.0) apply. Correspondence: Gustavo Moreno López (MA student), University of Guanajuato, Division of Social Sciences and Humanities, Guanajuato, MEXICO. E-mail: gustavo.moreno.lopez@hotmail.com. 


\subsection{Background on social phenomenon}

In its LIV presentation, the Super bowl had in the halftime show the performance of Shakira and Jennifer López as the leading voices, accompanied by Emme Muñiz J. Balvin and Bad Bunny. The presentation of the five Latino descendants was a matter of good and bad critiques. The last two mentioned singers performed their most famous reggaeton tunes in the last Super Bowl show. They also play a song with Jhay Cortez, one of the most reproduced songs on Youtube, with 1,030,846,810 views in only one year, from 17 May 2019-17 May 2020. In the next section, I will refer to the singers' impact on social media by mentioning the number of followers they have compared to other relevant personalities.

For instance, monthly on Spotify, J. Balvin has 50,285,038 listeners, while Bad Bunny has 41, 042, 519 listeners. These singers have more followers than relevant politicians, academics, and other public figures. This fact is a common trend in social media; the numbers that I state are referred to as followers. On Instagram, one of the most critical academics, an emeritus member of CONACyT and emeritus professor at the Colegio de México, Lorenzo Francisco Meyer Cossio does not even have an Instagram account. The richest man in Mexico, Carlos Slim has 16,700. Followed by two every day mentioned men in the Mexican news, Marcelo Ebrad with 40,900 and Hugo López-Gatell, who has 186,000. Two well-known Mexican cinematographers, Guillermo del Toro and Alfonso Cuaron, have 394,000 and 585,000, respectively. The current president of Mexico, Andres Manuel López Obrador, has 665,000. The current president of the United States, Donald Trump, has 19,800,000. Obama, the ancestor president of the United States is still more popular with 28,000,000, he has more than 1 million added followers than Bad Bunny, but no one of the previous people mentioned has more followers than J. Balvin, who has 40,200,000 followers.

On Facebook, the singers have fewer followers only than Obama and Trump with 55,393,331 and 27,657,156, respectively. J. Balvin has 19,000,000, and Bad Bunny has 3,900,000. The other influential personalities, such as Andres Manuel López Obrador has 6,820,091. Followed by Hugo López-Gatell with 867,996, there are Lorenzo Francisco Meyer Cossio with 51,456 and Guillermo del Toro with 303,597. At the end of the list, Carlos Slim, with 70,567, Marcelo Ebrad with 225,000, and Alfonso Cuaron, who has not officially personal Facebook account but in his official fans page, he has 15,297 followers.

On Twitter, Obama and Trump are on the top with 117,700,000 and 80,100,000, respectively. Followed by J. Balvin, who has 7,800,000 and Andres Manuel López Obrador has 7,000,000, there is Guillermo del Toro with 1,900,000, Marcelo Ebrad with 1,800,000, and Hugo López-Gatell with 1,000,000. Then, there is Lorenzo Francisco Meyer Cossio with 839,400, Bad Bunny with 637, 800, and Alfonso Cuaron with 327,500. Finally, Carlos Slim has not an official page, but his foundation official account has 79,700 followers. Compared to the social media of the singers with other influential personalities' accounts, it can be stated that in Spotify, they are the most played singers. On Instagram, the singers have more viewers than Obama. On Facebook and Twitter, the singers have fewer than Obama and Trump, but they still have more than several influential people. This data represents the influential importance of reggaeton singers on relevant platforms, especially from J. Balvin and Bad Bunny. Therefore, I decided to analyze their most outstanding song.

\subsection{The introduction of the singers}

Concerning the importance of the reggaeton singers, it is essential to state their music definition and their backgrounds. Reggaeton is defined by Collins dictionary (n.d.) as "a type of Puerto Rican popular music that combines reggae rhythms with hip-hop influences and includes rapping in Spanish." It means that the origins of this music come from Latin America, especially from Puerto Rico. 
J. Balvin's real name is José Álvaro Osorio Balvin; he was born in Medellín, Colombia, in 1985 . He has been in the music business since 2004 and been awarded a Latin Grammy by the best urban song in 2015, 2016, and 2018 by the best urban album.

Bad Bunny's real name is Benito Antonio Martínez Ocasio; he was born in Vega Baja, San Juan, Puerto Rico, in 1994. He has been in the music business for five years, and he was awarded by the urban album in 2019 Latin Grammy.

Jhay Cortez's real name is Jesús Manuel Nieves Cortez; he was born in Rio Piedras, Puerto Rico, in 1993. He has been in the music business since 2011. These three singers represent the origins of reggaeton, and their most famous song, "No me conoce", will be analyzed with the following methodology.

\section{Methodology}

The present paper uses a multidimensional discourse analysis, which consists of a "Three-dimensional method of discourse analysis" (Fairclough, 2013) as well as a study that is composed of a three-level analysis of the text, which includes its description and analysis, its process of production and interpretation. For this last step, I claimed for the help of a Colombian friend (will be called Ivan in the study), who has lived in Puerto Rico since there are lexicon and phrases that are not easy to comprehend even if it is in Spanish. Finally, I present the social explanation of the issue that is addressed and a general view of the elements that support the three levels to provide the concluding remarks concerning the social implications that the video highlights with certain statistical information. I will start by exploring the literature of Critical Discourse Analysis.

\subsection{Critical discourse analysis}

Critical discourse analysis (CDA) is the "study of the relations between discourse, power, dominance, social inequality and the position of the discourse analyst in such social relationships" (Van Dijk, 1993: 249), and it refers to the exploration of participants' role during any speech act, considering diverse variables, for example, sender, receiver, setting, code, and among other, previously mentioned. In this case, I will consider certain aspects of power and position that the singers have on social medial.

\subsection{Multimodal discourse analysis}

Regarding the multimodal discourse analysis (MDA), it is defined by O'Halloran (2011) as "the study of language per se to the study of language in combination with other resources, such as images, scientific symbolism, gesture, action, music and sound" (p. 120), it means that different discourse analysis framework can be combined for a better interpretation of the discourse. Therefore, I will analyze this video with systemic functional linguistics and visual semiotic frameworks, which are explained in the following sections.

\subsection{Systemic functional linguistics}

Halliday, Matthiessen, and Butt have interpreted systemic functional linguistics (SLF) framework since the 6os. This framework is also called systemic functional grammar (SFG) and is the main foundation of CDA as well as other theories in pragmatics. The main objective of this framework, according to Hu Zhuanglin (1988) is to: 
"reveal that language is a means of social interaction, based on the position that language system and the forms that make it up are inescapably determined by the uses or functions which they serve. Functional grammar aims to explain the internal relations in language as a system network, or meaning potential. And this network consists of subsystems from which language users make choices." (as cited in Wang, 2010: 255)

The previously mentioned refers to the study of grammatical features to construct a meaning for the discourse. Moreover, Halliday and Matthiessen (2013) distinguish for the analysis, interpretation, and evaluation of the speech, three metafunctions: ideational, interpersonal, and textual, which are influenced by field, tenor, and mode, respectively.

- Ideational metafunction represents the language of current experience and considers participants, grammar, and processes.

- Interpersonal metafunction focuses on the relationships with the tenor and the audience.

- Textual metafunction evaluates the logical construction of sentences.

\subsection{Visual semiotic analysis}

Multimodal studies focus on "words, on a record sleeve, the contents and style, the poses of the artists, the kinds of melodies and sounds they produce, the words they choose for their lyrics all connote discourses" (Machin, 2010: 7). Therefore, in a music video, it is essential to analyze the visual semiotic features, such as postures, objects, settings, gaze, social distance, salience, and modality. Following this multimodal framework, I will present the data analysis in the following section.

\section{Results}

In this section, I will provide the analysis of the lyrics by the number of tokens and types (see Table 1) in the song of the music video, "No me conoce" by J. Balvin, Bad Bunny and Jhay Cortez.

Table 1. Tokens and types in the song's lyrics

\begin{tabular}{ll}
\hline & No. \\
\hline Tokens & 804 \\
\hline Types & 210 \\
\hline
\end{tabular}

Table 1 shows the analysis of the Interpersonal metafunctions, which categorize the declarative and the imperative mood. There are only 210 types that are repeated four times. It means that in 5:06 minutes, the same lyrics are pronounced four times. It is a matter of quality, not quantity.

\subsection{Metafunctions}

In this section, I provide work with the SFL proposed by Halliday (1978) to evaluate the lyrics through a grammatical analysis using the three metafunctions. Moreover, it is necessary to state that certain types will be presented in Spanish since there is no literal meaning in English in several cases. However, the language distance is closed by the interpretation of the most relevant words. 


\subsubsection{Ideational metafunction}

The first metafunction is concerned with the transitivity of the real phenomena, which includes six processes: material, mental, relational, verbal, behavioral, and existential. The verbs from the lyrics were obtained and classified as in Table 2.

Table 2. Ideational processes

\begin{tabular}{llrl}
\hline Process & Function & Examples: \\
\hline Material & Something is done & E.g. Se volvió (turn), have (tiene), drink, smoke \\
\hline Mental & $\begin{array}{l}\text { Perception } \\
\text { reaction } \\
\text { cognition }\end{array}$ & $\begin{array}{r}\text { E.g. Se hace (pretend), se deja ver (meet), sabe disimular } \\
\text { (pretend) }\end{array}$ \\
\hline Relational & $\begin{array}{l}\text { Identifying, } \\
\text { attributive }\end{array}$ & E.g. Estás a vapor (you are), se pone loca (get mad) \\
\hline Verbal & Interaction & E.g. Me conoce 1, me sigue (follow), say, call \\
\hline Behavioral & Feelings & E.g. look, want, like \\
\hline Existential & $\begin{array}{l}\text { Somethings } \\
\text { or happens }\end{array}$ & exists & E.g. pretend, wear, dress
\end{tabular}

Note. Samples of ideational metafunction

Table 2 illustrates the most repeated verbs: pretend, meet, fuck, and know. These words construct the image of a person with a double life; it means that this subject is someone different in private and in public scenarios. In addition to the previous idea, I provide the following sentences in the song that I discuss with Ivan:

The first sentence appears seven times in the song, and it uses three of the most repeated verbs, pretend, meet, turn:

"Se hace la que no me conoce, pero en mi cama se volvió un vicio"

This phrase means that a woman pretends to act as if she does not know a man, even when they have had intimacy. The next sentence uses two verbs and expresses an urban saying to have sex:

"Me la como entera y nadie se entera"

I discuss the previous sentence with Ivan, saying that comer, which could be interpreted as "eat" in English, is commonly used in Colombia to say that a person has had sex with someone else. So, this sentence states that they have sex, but nobody knows. The following sentence occupies three verbs:

\section{"Preguntan y dice no sé de contacto tiene Jose"}

It means that when any person asks about a possible relationship, she refuses and hides their relationship. Additionally, she keeps private her social media, as the following sentence mentions:

\section{"Instagram privado para que nadie la vele"}

This previous sentence uses only one verb at the end, vele. Ivan mentioned that it refers to the verb "discover", which means that she tries to hide something in social media. The next phrase uses two verbs:

"Para portarse mal, se viste bien" 
It means that she wears appropriately to misbehave, which refers to the idea that she changes her personality as she changes her clothes. In the last sentence, there are two verbs:

"Que si me conoce dice no, pero sabe bien que si"

This sentence refers to the fact of hiding a relationship since she rejects to know him, but she does. Ivan states that the song can be summarized in the phrase "married at home but single outside", which means that the subject has two faces. In addition, the majority of actions direct mental, followed by behavioral and material processes, which indicates that there is attention to feelings and perceptions in short in simple sentences. I will now pronounce the second metafunction.

\subsubsection{Interpersonal metafunction}

The second metafunction is interpersonal; it includes an analysis of the actions of the lyrics. In this case, I present an evaluation of declarative and imperative sentences, as seen in Table 3 .

Table 3. Interpersonal sentences

\begin{tabular}{ll}
\hline Declarative (For information) & Ella mata, yo le di, ella lo mezcla, \\
\hline Imperative (Commands) & $\begin{array}{l}\text { hace, volvió, sigué, sabe disimular, gusta } \\
\text { portarse, mira, no me conoce, }\end{array}$ \\
\hline
\end{tabular}

Note. Samples of declaratives and imperatives

Table 3 provides examples of declarative and imperative sentences, and two facts can be stated. First, declarative clauses represent only less than $20 \%$ of all the clauses, which means that there are limited complete sentences and that $70 \%$ of declarative sentences use the pronoun she. On the other hand, the imperative clauses are $80 \%$ of the sentences, which means a lack of subjects and let the actions in doer anonymity. I will now proceed to outline the textual functions that were identified in the lyrics.

\subsubsection{Textual metafunction}

The third metafunction is textual, which refers to specific linguistic features in which the singers denote repetitive messages. Regarding this study, I will focus on modal verbs, tenses, adjectives, pronouns, and connectors. Initially, I start with an examination of modal verbs, and as a result, there was not any identified. This lack illustrates the absence of politeness in the song.

Tenses were the next feature to evaluate; I classified them into the most verbal tenses in the language, which are present perfect, simple present, present continuous, future simple and simple past, as seen in Table 4 .

Table 4. Tenses analysis

\begin{tabular}{llll}
\hline & Examples & No. & $\%$ \\
\hline Present perfect & -- & -- & -- \\
\hline Present simple & Want, like, know, & 46 & $82 \%$ \\
\hline Present continuous & -- & -- & -- \\
\hline Future simple & -- & -- & -- \\
\hline Simple past & Came back, wore, gave & 10 & $18 \%$ \\
\hline
\end{tabular}

Note. Statistics of tenses evidence 
Table 4 provides the analysis of five tenses in the lyrics, and it can be stated that there are used only two. There is not a sentence in present perfect, present continuous, or future simple. Moreover, the sentences in the simple past represent $18 \%$ of the lyrics and present simple $82 \%$. It means that the song refers to actions in everyday and future episodes and that the actions will not change, and they are defined as permanent. For example, in the phrase, "Nunca dice no, siempre dice sí" and "siempre después de las once o doce me tira para que yo la pruebe", it is taken from granted that the woman is always going to accept or to propose to meet him. In the next section I evaluate the adjectives. The adjectives were taken from the lyrics and classified into positive and negative; this classification denotes the optimistic and destructive impact of the adjectives implied, as seen in Table 5.

Table 5. Adjectives use

\begin{tabular}{llll}
\hline & Example & No. & $\%$ \\
\hline Positive & Sport, small, chiquitita, grandota, buena, & 5 & $36 \%$ \\
\hline Negative & Raro, solteras, loca, olorosa, privado, & 9 & $64 \%$ \\
\hline & Total: & 14 & $100 \%$
\end{tabular}

Note. Statistics of adjectives presence

Table 5 provides the only ten adjectives that are used in the entire song. There are five negative adjectives in the phrase, "todas solteras siempre la velan para que ella siga", it means that the single women are the ones that motivate and hide a double life. There are five positive adjectives as well. For example, in the sentence, "ella mata con traje y cuando se viste sport", it means that the woman looks good in casual and sport clothes or can make allusion to her absolute beauty a part from any scenario. However, negative references are repeated predominantly. I will now pronounce the use of subjects in the lyrics.

In the entire song, I took the personal pronouns, counted them, and classified them into first, second, and third person, as seen in Table 6.

Table 6. Personal pronouns use

\begin{tabular}{llll}
\hline Person & Examples & No. & $\%$ \\
\hline First & I & 8 & $32 \%$ \\
\hline Second & - & - & \\
\hline Third & She & 16 & $64 \%$ \\
& They & 1 & $4 \%$ \\
\hline & Total: & 25 & $100 \%$ \\
\hline
\end{tabular}

Note. Statistics of pronouns evidence

Table 6 shows three relevant facts that the first subject, "I" is used in limited eight times. That there is no evidence of incorporating a second person and that the personal pronouns, "she" and "they" are used sixteen and one times, respectively. Furthermore, it is interesting to see those three-man singers refer to them by using "I" only eight times while they refer to an only woman the double of times they do refer to themselves. For instance, in the solo intervention of J. Balvin, he refers to the subject "I" only once but continuously attached the actions to the woman as in "ella se vistió, ella se pone loca, ella lo mezcla", which is fair not equitable. In the following section, I will proceed to illustrate the connectors in the lyrics.

The entire song was analyzed to obtain continuative and conjunction examples, which were later classified in the previously stated categories, as seen in Table 7. 
Table 7. Connectors in the lyrics

\begin{tabular}{llll}
\hline Feature & Example & No. & $\%$ \\
\hline Continuative & Yes, no, eh, yeh, ah, na & 33 & $26 \%$ \\
\hline Conjunctions & And, but, to, if, that, as & 93 & $74 \%$ \\
\hline & Total: & 126 & $100 \%$ \\
\hline
\end{tabular}

Note. Statistics of connectors' presence

Table 7 distinguishes the most outstanding continuatives, such as eh, yeh, na; those words mean nothing in any language and are used as connectors in $26 \%$ of the lyrics, especially at the start and at the end of the song. Conjunctions represent the $74 \%$ of connectors with words as "to" and "but" as in the following phrases, "a portarse mal, para sentirse bien", "no queria fumar, pero le dio al pen", "una Barbie, pero no busca un Ken". The first phrase is a common saying in Colombia to get ready for a party; the second means that instead of smoking, she consumed another drug, and the last states that she is not interested in a formal relationship. Those previous sentences have two main problems; they do not even have a subject and excessively use conjunctions, which can make them challenging to interpret and wordy. I will pronounce the last multimodal facet of this study, which constitutes an evaluation of the images in the next section.

\subsection{Visual semiotic analysis of the song's video}

Finally, I present the visual semiotic analysis using Machin's (2010) suggested connotators for the analysis of music, images, and sound. I will describe the most relevant aspects that appeared on the video scenes, including frames from the music video that exemplified the statements of certain aspects, such as postures and objects.

\subsubsection{Postures}

Apart from the multiple scenes of the woman, the last scene of the video is the pose in which she changes from being inside to get out and has a transformation in her indoors and outdoors personality (see Image 1).

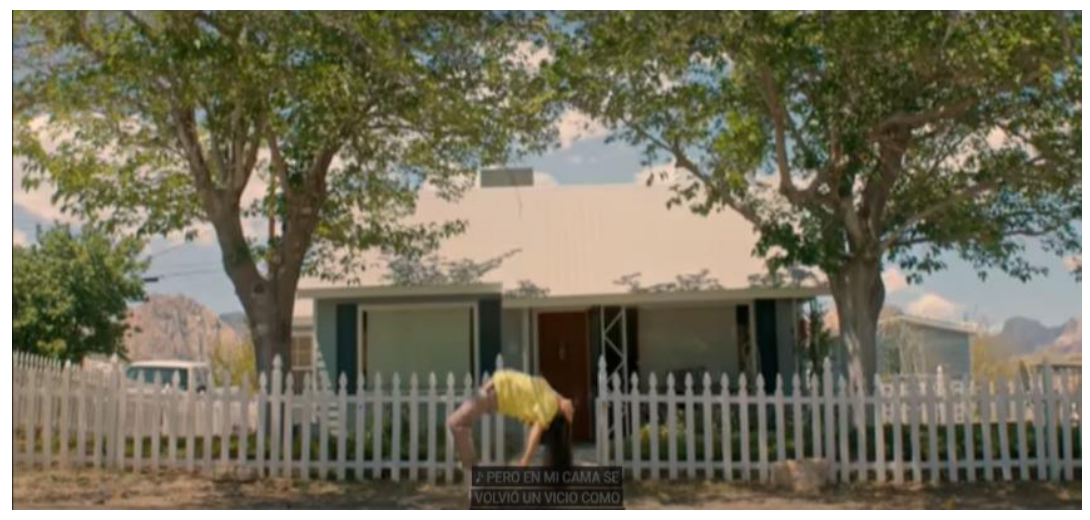

Image 1. The woman poses (Source: J. Balvin, Bad Bunny and Jhay Cortez "No me conoce")

The same happens in Image 2, with a man's pose while he is on the street, he changes his behavior when he is inside around the other two men dancing and when he is the scene by himself. 


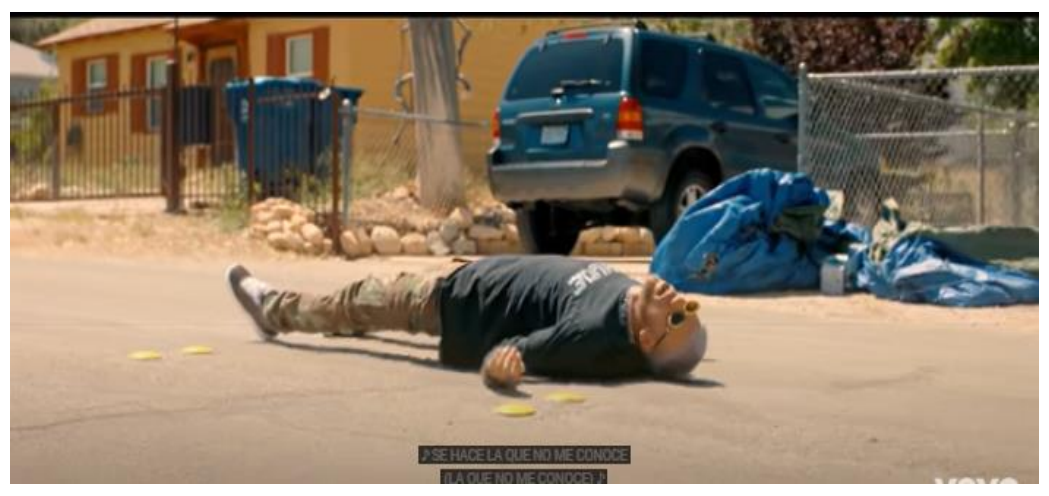

Image 2. The man poses (Source: J. Balvin, Bad Bunny and Jhay Cortez "No me conoce")

\subsubsection{Objects}

The objects that continuously change from scene to scene are clothes, especially the clothes of the woman when she is indoors, when she is on the public lights, and when she is in the dark.

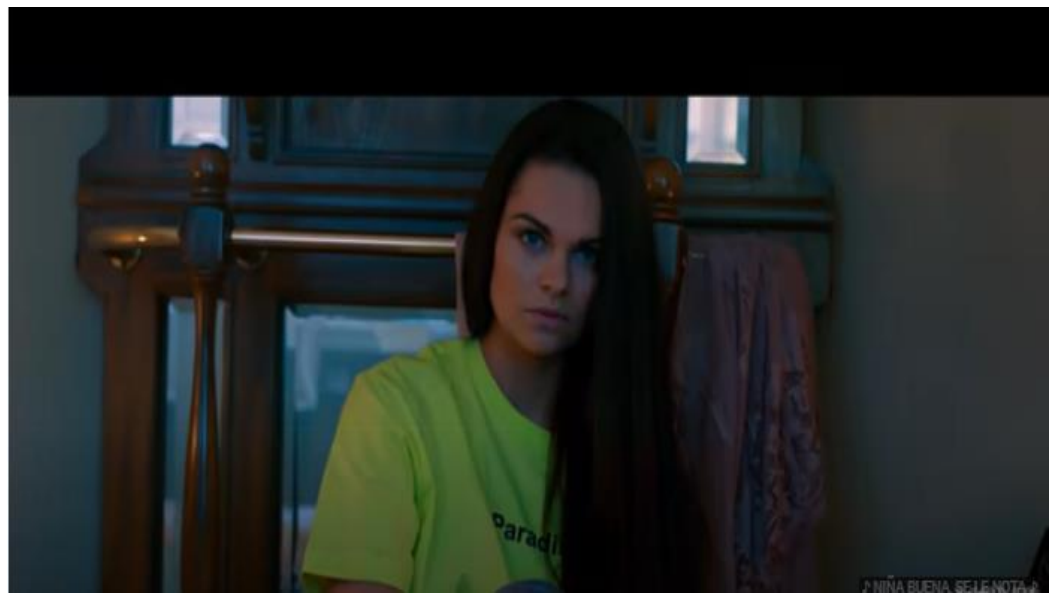

Image 3. The woman indoors (Source: J. Balvin, Bad Bunny and Jhay Cortez "No me conoce”)

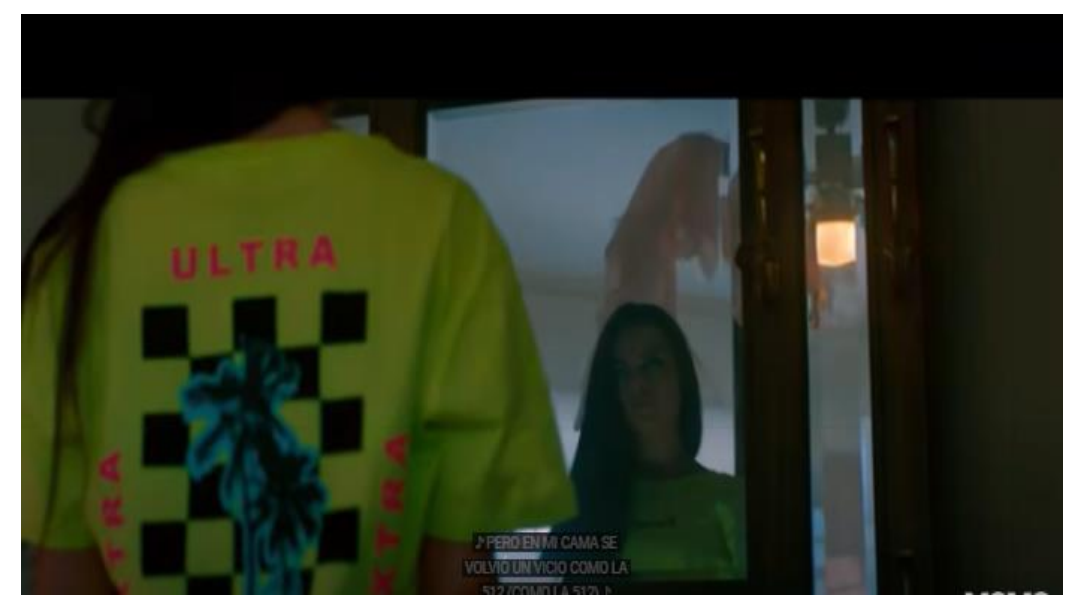

Image 4. The woman clothes (Source: J. Balvin, Bad Bunny and Jhay Cortez "No me conoce") 


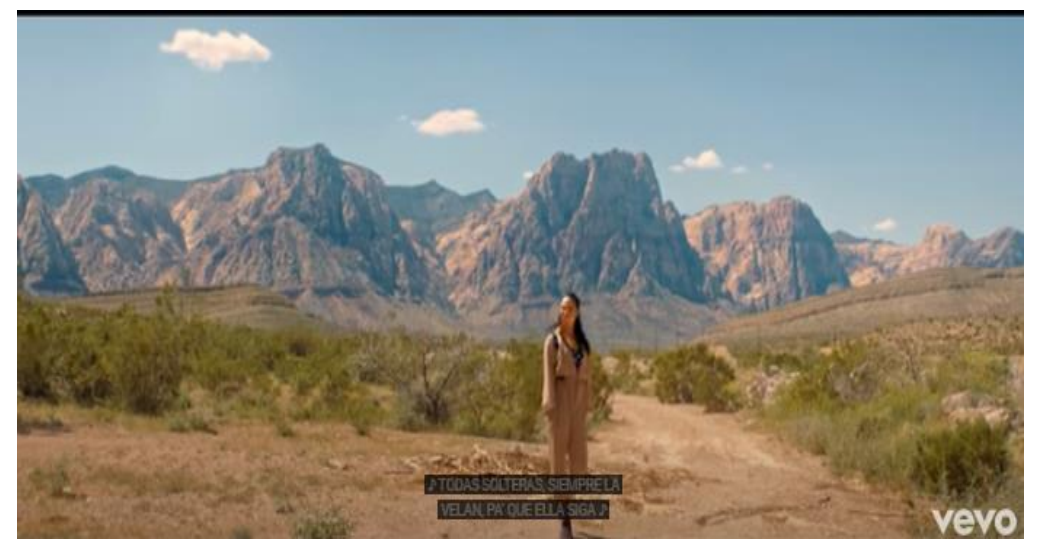

Image 5. The woman in lights (Source: J. Balvin, Bad Bunny and Jhay Cortez "No me conoce”)

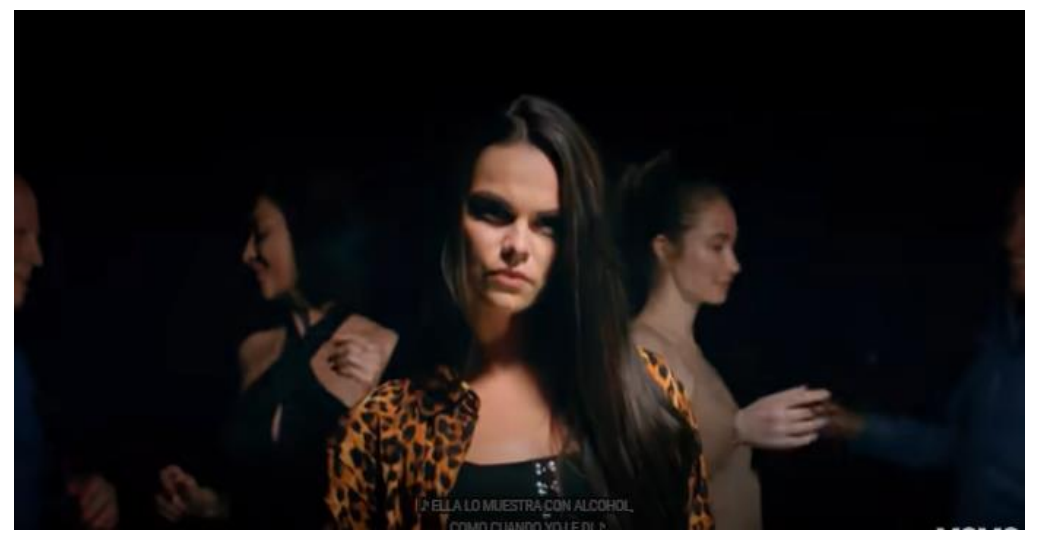

Image 6. The woman in dark (Source: J. Balvin, Bad Bunny and Jhay Cortez "No me conoce")

Image 3 illustrates a woman with sport and bright clothes. Additionally, in the indoor scenes, there is lingerie around the top fan (see Image 4). Image 5, the woman wears a complete opaque dress with a serious personality. Finally, on Image 6, the woman wears black and animal print clothes. Through the changes of clothes her personality changes as well from quiet to angry and dominant.

\section{Discussion}

Through the multimodal analysis with the use of SFG (metafunctions) and visual semiotic frameworks, it is perceived that the singers refer to the woman as a double life person. For instance, the ideational metafunction, specifically the behavioral process and the semiotic analysis of the images, indicates that she pretends to turn her personality into something different depending on the context. Concerning the textual metafunction, there is evidence of lack of responsibility from the man's claims about the woman. There is evidence of a negative reference to the woman as well as sexual connotations in the textual metafunction. For instance, the words joder, comer, dar por el expreso, lo metí en cuatro, and tirar para probar, denote varied ways of referring to sexual associations.

Moreover, the three metafunctions demonstrate a lack of vocabulary and syntactic accuracy since there are only 210 types represented in 804 tokens. It means that in 5:06 minutes, the same lyrics are pronounced four times. It is a matter of quality, not quantity, and this song has repetitive lexis and limited grammatical structures use. Those aspects are important to observe since reggaeton is the most consumed and popular genre in Latin America and it contributes 
extensively negatively to educational stances, such as writing proficiency, lexicon knowledge, and reading comprehension.

\section{Conclusion}

In conclusion, I presented a multimodal discourse analysis of the most viewed and influential video on Youtube, "No me conoce" by J. Balvin, Bad Bunny, and Jhay Cortez. I used for the study Machin (2010) Visual Semiotic Analysis and Halliday and Matthiessen's FSL (2013), I explored the most relevant aspects that the singers use in order to offer a social critique concerned with the negative connotations of reggaeton. Certain authors (Gallucci, 2008; Noriega, 2014; Ramírez, 2012) in Latin America have stated that this genre provides a bad image of the woman and sexual associations. These ideas were validated in this study since the lyrics and images present evidence of a negative impact on the woman's role and its relation to sexual content. However, this study also denotes the inadequate lexis and grammatical structures used in this song, which can have a negative impact on the consumers. In addition, there is evidence of misinformation and misinterpretation occur through the absence of reflective listening and analysis of music and although the musical preferences need to be respected, the music's messages need to have back sources of quality and constructive references to be more positively meaningful for listeners. For instance, educational stances, such as writing proficiency, lexicon knowledge, and reading comprehension, can be affected by the consumption and popularity of this genre since we are what we eat, but we are what we hear as well.

\section{Acknowledgements}

I would like to mention the support and advise from my professor Dr. Troy Crawford.

This research did not receive any specific grant from funding agencies in the public commercial, or not-for-profit sectors.

The author declares no competing interests.

\section{References}

Brown, G., \& Yule, G. (1983). Teaching the spoken language. Cambridge: Cambridge University Press.

Drid, T. (2010). Discourse analysis: Key concepts and perspectives. Modern Language Journal, 8(3), 2020. Retrieved from

https://scholar.google.com.mx/scholar?hl=es\&as sdt=0\%2C5\&q=Discourse+analysis+key+ concepts+and+perspectives\&btnG.

Fairclough, N. (2013). Critical discourse analysis: The critical study of language. New York, NY: Routledge.

Gallucci, M. J. (2008). Análisis de la imagen de la mujer en el discurso del reggaetón. Opción, 24(55), 84100. Retrieved from https://www.redalyc.org/pdf/310/31005506.pdf.

García, M. U. (2010). El reggaetón, invitación al sexo. Análisis lingüístico. Temas de comunicación, (20), 141-160. Retrieved from

http://revistasenlinea.saber.ucab.edu.ve/temas/index.php/temas/article/viewFile/417/417.

Halliday, M. A. K., \& Matthiessen, C. M. (2013). Halliday's introduction to functional grammar. New York, NY: Routledge.

Machin, D. (2010). Analysing popular music: Image, sound and text. London: Sage Publications. 
Noriega, D. A. M. (2014). Música, imagen y sexualidad: el reggaetón y las asimetrías de género. El cotidiano, (186), 63-67. Retrieved from https://www.redalyc.org/pdf/325/32531428010.pdf.

O’Halloran, K. L. (2011). Multimodal discourse analysis. In K. Hyland \& B. Paltridge (Eds.), The continuum companion to discourse analysis (pp. 120-136). London: Continuum International Publishing Group.

Reggaeton. (n.d.). In Collins dictionary. Retrieved from https://www.collinsdictionary.com/es/diccionario/ingles/reggaeton.

Stubbs, M. (1983). Discourse analysis: The sociolinguistic analysis of natural language. Chicago, IL: The University of Chicago Press.

Van Dijk, T. A. (1993). Principles of critical discourse analysis. Discourse \& Society, 4(2), 249-283. Retrieved from https://pdfs.semanticscholar.org/od73/e64bc29f17c0986661fd6e8dcd3316acad76.pdf.

Van Els, T. (1984). Applied linguistics and the learning and teaching of foreign languages. London: Edward Arnold.

Wang, J. (2010). A critical discourse analysis of Barack Obama's speeches. Journal of language teaching and research, 1(3), 254-261. Retrieved from

http://www.academypublication.com/issues/past/jltr/volo1/03/12.pdf. 